\title{
PAX8/PPARG Fusion Protein
}

National Cancer Institute

\section{Source}

National Cancer Institute. PAX8/PPARG Fusion Protein. NCI Thesaurus. Code C99366.

A fusion protein encoded by the PAX8/PPARG fusion gene. This protein is comprised of the $\mathrm{N}$-terminal DNA binding domain of paired box protein Pax-8 and the entire peroxisome proliferator-activated receptor gamma protein, including the ligand binding, DNA binding and activation domains. 